\title{
THE THIRD UNITED NATIONS CONFERENCE ON THE LAW OF THE SEA: WHAT WAS ACCOMPLISHED?
}

\author{
TOMMY T. B. KOH*
}

At the Law of the Sea Conference we have acquired a vocabulary all our own. We have short forms for referring to concepts, even to groups of people and delegations, and something quite interesting happened one day when my predecessor in office and former president of the conference, Ambassador Amerasinghe, was dictating the draft of a speech to a gathering like this. He said to his secretary, "The coastal states fall into two categories: There are, first of all, those who claim a territorial sea of 200 miles, whom I shall hereafter refer to as the 'territorialists,' and there are other coastal states who have claimed an economic zone of 200 miles, whom I shall hereafter refer to as the 'zonists'." When the script came back from his secretary it read, "There are two groups of coastal states: On the one hand there are the 'terrorists' and on the other hand there are the 'Zionists'." I told him that there were some Freudian insights in her typographical mistakes.

I would like to perform the function of providing you with a brief overview of the accomplishments of the Conference. Professor Stefan Riesenfeld will take on the role of pointing out to you what the Conference failed to accomplish.'

Let me begin by saying that this Convention, the United Nations Convention of the Law of the Sea, which was adopted on the 30th of April, is the first comprehensive convention covering all aspects of the uses and resources of the sea. It is, therefore, in this respect very different from the four Geneva Conventions of 1958, 2 which dealt with limited aspects of the law of the sea. But I should add here that the fact that the Convention is comprehensive, the fact that it attempts to deal with all aspects of the uses and resources of the sea, does not necessarily mean that it succeeded in living up to what the father of the Conference, Dr. Arvid Pardo, had enjoined us to do in 1967, namely, to adopt a constitution or a charter of the sea that would deal with ocean space as an organic and ecological whole. I will leave it to Dr. Arvid Pardo, who will be speaking to us at one of our subsequent functions, to discuss whether or not this Convention has achieved that objective.

The second point which I want to make about this Convention is that it not

\footnotetext{
Copyright (C) 1983 by Law and Contemporary Problems

* Permanent Representative of Singapore to the United Nations; President. Third United Nations Conference on the Law of the Sea.

1. See Riesenfeld, Comment, Law \& Contemp. Probs., Spring, 1983, at 11.

2. 1958 Geneva Convention on the Territorial Sea and Contigious Zones, 15 U.S.T. 1606. T.I.A.S. No. 5639, 516 U.N.T.S. 205; 1958 Geneva Convention on the Continental Shelf, 15 U.S.T. 471, T.I.A.S. No. 5578, 499 U.N.T.S. $311 ; 1958$ Geneva Convention on the High Seas, 13 U.S.T. 2312. T.I.A.S. No. 5200,450 U.N.T.S. 82; 1958 Geneva Convention on Fishing and Conservation of the Living Resources, 17 U.S.T. 138, T.I.A.S. No. 5969, 559 U.N.T.S. 285.
} 
only codifies existing international law, but that it also contains many new and innovative concepts of international law. These new concepts of international law were created in response to the advance of technology, to the demand, especially by the developing countries, for greater international equity, and by the new uses of the sea and its resources.

Let me just mention a few examples to illustrate my second point. In recent decades, there has been a revolutionary advance in fishing technology. A limited number of developed countries possess factory fishing ships equipped with electronic tracking gear. This advance in fishing technology has enabled these countries to increase the harvest of fish from the sea in a very radical fashion, so much so that in some areas of the sea there has been overfishing, leading to the depletion or threatened depletion of certain species. This in turn has stimulated the coastal states to raise the alarm that unless the world adopts a different approach towards the management and conservation of its fishery resources, there is a very real danger that in the long term the world will confront a very serious crisis in the living resources of the sea. This is, at bottom, the raison d'être of the demand by coastal states for the establishment of an exclusive economic zone of 200 miles in which the coastal state will have sovereign rights to the resources.

The argument of the coastal states is that ninety-nine percent of the world's fish catch comes from within this belt of 200 miles. Only one percent of the world's fish catch, mainly tuna, comes from outside the economic zone. The coastal states argue that if they have the responsibility to manage and conserve the fish stock within the economic zone, they are more likely to do an adequate job than they would under the traditional law which imposes a rather narrow belt of the sea over which the coastal state has jurisdiction and beyond which there is the high sea freedom to fish. ${ }^{3}$

Another example of the advance of technology which has produced a change in international law is the advance of offshore exploration for oil and gas. As a result of the advance in the technology for exploiting oil and gas in the continental shelf, coastal states have demanded an extension of the rights beyond the continental shelf to the continental slope, to the continental rise, and even to ridges beyond the rise. Whether this is a good thing or not depends on one's perspective, and I shall come back to my evaluative judgment in a moment.

Another area in which there has been a major advance in techonology which has had an impact on the law is in the field of shipbuilding. In recent decades, as we all know, the advance in shipbuilding technology has evolved, for example, the very large crude carriers. Some that call at my port in Singapore are 500,000-ton supertankers We have also seen the evolution in recent years of nuclear-powered submarines and nuclear-armed submarines. We have seen a tremendous increase in the world's merchant tonnage. This has led to congestion of sealanes; it has led to accidents which have had a deleterious effect on the marine environment.

3. For a discussion of the traditional international regime applicable to fisheries, see Carroz. The Richness of the Sea: Fisheries, in THE FUTURE OF THE LAW OF THE SEA 77. 85-90 (1973). 
These changes in technology have had, therefore, an impact on the law, and some of the new provisions in the Convention were evolved in response to these changes.

The next point which I would like to make is that in the period between 1945 and the conclusion of the Conference this year, we have seen a breakdown of the traditional limit of three miles for the territorial sea. We have seen unilateral claims by coastal states of 12 to 200 miles, resource zones stretching from 12 to 200 miles and even more, and a plethora of other claims to resource rights as well as to jurisdictions.

I think a major achievement of this Conference has been that we were able to agree upon many important limits on the different maritime zones of coastal states, such as the territorial sea, the contiguous zone, the exclusive economic zone, and the continental shelf. ${ }^{4}$ We have also agreed upon regimes of passage of ships through and of aircraft over the critical sealanes of the world. ${ }^{5}$ And we have clearly established the rights and obligations of the coastal states on the one hand, and of the international community on the other. ${ }^{6}$ In this way I believe the Convention has made a significant contribution to the promotion of peace and security and of law and order in the ocean.

My fourth point deals with the protection and preservation of the marine environment, which I believe is an interest of the entire world community. The Convention contains some important and new provisions on this question. ${ }^{7}$ In their totality, these provisions represent a significant advance in our common struggle to protect and to preserve our marine environment.

Fifth, the Convention has made a significant contribution to the elaboration of a comprehensive set of rules on marine scientific research. ${ }^{8}$ I know that these new rules are not universally liked, particularly by our colleagues who are marine scientists. I had occasion two years ago to speak to the Woods Hole Oceanographic Research Institute, and when I explained to them the consent regime that is embodied in the Convention, their first response was one of horror and of opposition. I then had to explain to the marine scientists that the choice before them was not between the traditional law of unfettered freedom of marine scientific research and the consent regime in the Convention. The choice before the marine scientists is the consent regime with all the safeguards we have negotiated within the Convention and no internationally accepted rules at all. It is my conviction that given those two choices, it is in the interest of the marine scientists, and therefore of the world community's interest in the promotion of marine scientific research, to support the regime in the Convention.

Sixth, unlike most other treaties under which there are no mandatory provisions on the settlement of disputes, a very unique feature of the new Convention is that it does contain mandatory provisions on the settlement of disputes. ${ }^{9}$ I believe

\footnotetext{
4. See Convention on the Law of the Sea, opened for signature Dec. 10, 1982, U.N. Doc. A/CONF.62/122 (1982), pts. II, V.VI, reprinied in 21 I.L.M. 1261 (1982).

5. See id. pt. III.

6. See id. passim.

7. See id. pt. XII.

8. See id. pt. XIII

9. See id. pt. XV.
} 
that this is another significant contribution of the Convention to the cause of peace in general, and to the strengthening of the principle of the peaceful settlement of disputes between states and the nonresort to force in the settlement of disputes between states in particular.

Seventh, for those of us who care about the preservation of marine mammals such as whales and dolphins, the Convention enjoins states to cooperate with appropriate international organizations for their conservation, management, and study. ${ }^{10}$ Although this is admittedly only a small step because some of the whaling nations prevented us from taking a much larger step in this direction, it is nevertheless a step in the right direction.

Eighth, I believe that in the contentious area of the mining of the mineral resources of the international areas of the seabed and ocean floor, a fair and workable regime has been negotiated. ${ }^{11}$ In this respect, I refer not only to the provisions in Part XI of the Convention, but just as importantly, I refer to Resolution II, which was adopted by the Conference in April and which formed an integral and inseparable whole with the Convention. Under Resolution II the consortia and states which have already invested research and development funds in the exploration of specific mine sites have been recognized. If the state to which a consortium belongs signs the Convention, the consortium may be registered as a pioneer investor. In the case of a consortium which is unincorporated, and which consists of partners from a number of different countries, the consortium may be registered as a pioneer investor if only one of the countries to which the consortium partners belong signs the Treaty. Upon being registered as a pioneer investor, the consortium acquires the exclusive right-and I want to underline this - it acquires the exclusive right to explore its specific mine site in the deep seabed and ocean floor. And when the Convention comes into force, the registered pioneer investor, so long as it complies with the requirements of the Convention, has an automatic right to a contract to mine that specific mine site. Thus, the troublesome question about guaranteed access to the resources of the deep seabed has been resolved.

The next question is how will the production limitations of the Convention affect these pioneer investors? In Resolution II, we have stated that the pioneer investor shall have priority in the allocation of the production authorizations calculated under the production formula. According to my friends who are more expert than I, the production limitation in the Convention poses more of an ideological than a functional problem for the United States. Why do I say that? I say that because according to these experts, which include American experts, given the economic prospects of the mining industry for the moment and in the foreseeable future, and given the limited number of operators who are likely to enter the field, any reasonable projection will give us a number of mine sites which can be exploited over the next twenty years adequate to accommodate all those who are likely to want to enter this industry.

My point here, therefore, is that the production limitation provisions of the

10. Id. arts. 65,120

11. See Third United Nations Conference on the Law of the Sea, adopted April 30, 1982, resolution II, U.N. Doc. A/CONF. 62/121 (1982). 
Convention may appear ideologically obnoxious to those who believe that the magic of the marketplace should not be improved by any other device. But this ideologically objectionable provision in the Convention will, in reality, have no bite. It will in reality have no bite because on any reasonable projections worked out by your own experts, it will have no limiting effect on the prospects of seabed mining.

I do not want to go on much longer because the Chairman is a very tough traffic cop and I have probably exhausted my time. The point I want to make on seabed mining is that $I$ believe that putting aside the ideological and philosophical problems which still remain, the Conference has, I think, addressed in a serious manner the functional and pragmatic needs of the mining industry and has tried to provide reasonable safeguards for those needs.

The last point I want to make before I close is to draw your attention to the unique process by which this Convention was adopted. Although the rules of procedure of the Conference do envisage voting, ${ }^{12}$ it has been a very remarkable feature of the Conference that not until the last day did the Conference ever resort to voting on any substantive matter in the Conference. The majority of the participants in the Conference have, from the very beginning, realized that the interests of the participating countries at stake are so serious, so substantial and in some cases, so irreducible, that however difficult, however intractable, we must negotiate until we find acceptable mutual accommodations for all these competing interests. Hence, we have always adopted the method of consensus for decisionmaking. It was, I think, somewhat ironical that on the last day of the Conference, it was the United States, the country which had all along emphasized the need to adhere to the procedure of consensus, which asked for a vote and which was one of the four countries that voted against the Convention.

Before I close, I want to leave you with seven questions:

(1) Has the Convention contributed to the maintenance of international peace and security?

(2) Has the Convention contributed to the conservation of the living resources of the sea?

(3) Has the Convention promoted the preservation of our marine environment?

(4) Has it protected the world community interests in navigation?

(5) Has it promoted world economic stability?

(6) Has it narrowed the gap between developed and developing countries?

(7) Has it promoted the world community interests in marine scientific research?

12. See Rules of Procedure of the Third UN Conference on the Law of the Sea, rule 37, reprinted in VI New DiRections on the LaW OF THE SEA 572 (1977). 
